DOI: https://doi.org/10.47405/mjssh.v6i11.1136

\begin{tabular}{|c|c|}
\hline 4 & Malaysian Journal of Social Sciences and Humanities (MJSSH) \\
\hline $\begin{array}{l}\text { Malaysian Juoural of } \\
\text { Social ccciecces and }\end{array}$ & Volume 6, Issue 11, November 2021 \\
\hline (MJ-sSH) & e-ISSN : 2504-8562 \\
\hline & $\begin{array}{l}\text { Journal home page: } \\
\text { www.msocialsciences.com }\end{array}$ \\
\hline
\end{tabular}

\title{
Kesahan dan Kebolehpercayaan Instrumen Penilaian Kendiri Pembelajaran Ungkapan Algebra Tingkatan Dua
}

\author{
Sarimah Binti Baco ${ }^{1}$, Mohd. Zaki Bin Ishak ${ }^{1}$ \\ 1Fakulti Psikologi dan Pendidikan, Universiti Malaysia Sabah (UMS), Malaysia \\ Correspondence: Sarimah Binti Baco (sari.ima67@gmail.com)
}

\begin{abstract}
Abstrak
Kesahan adalah sejauh mana instrumen mengukur apa yang hendak diukur dan kebolehpercayaan adalah keupayaan suatu kajian untuk memperoleh nilai yang serupa apabila pengukuran yang sama diulangi. Kesahan dan kebolehpercayaan instrumen amat penting bagi mempertahankan kejituan item soal selidik daripada kecacatan. Tujuan kajian ini adalah untuk menentukan kesahan dan kebolehpercayaan instrumen soal selidik penilaian kendiri pembelajaran Ungkapan Algebra Tingkatan Dua. Soal Selidik telah disahkan melalui kesahan muka dan kesahan kandungan instrumen yang melibatkan lima orang pakar dalam bidang Matematik dan dua orang pakar bidang Bahasa manakala kesahan konstruk dan kebolehpercayaan instrumen dianalisis menggunakan perisian Statistical Package of Social Science (SPSS) Versi 27.0. Seramai 145 orang pelajar Tingkatan Dua terlibat dalam kajian ini. Dapatan kajian menunjukkan indeks kesahan kandungan-item (I-CVI) berkisar antara 0.800 hingga 1.000 dan indeks kesahan kandungan-skala (S-CVI / Ave) adalah 0.973. Skor nisbah kesahan kandungan (CVR) menunjukkan bahawa semua item disahkan penting oleh pakar. Muatan faktor bagi setiap item berada dalam julat 0.539 hingga 0.846, manakala keputusan analisis kebolehpercayaan adalah $\alpha=0.950$. Keputusan menunjukkan instrumen mempunyai kesahan dan kebolehpercayaan yang tinggi dan sesuai digunakan untuk pelajar Tingkatan Dua menilai pembelajaran Ungkapan Algebra pada domain kognitif pengetahuan, kefahaman dan aplikasi. Implikasi kajian ini adalah guru akan mendapat maklumat tentang pembelajaran Ungkapan Algebra pelajar secara langsung daripada instrumen yang dibina.
\end{abstract}

Kata kunci: kesahan, kebolehpercayaan, pembelajaran ungkapan algebra, domain kognitif, penilaian kendiri

\section{Validity and Reliability of the Form Two Algebraic Expression Self- Assessment Learning Instrument}

\begin{abstract}
Validity is the extent to which an instrument measures what is to be measured and reliability is the ability of a study to obtain similar values when the same measurement is repeated. The validity and reliability of the instrument are very important in maintaining the accuracy of the questionnaire items from defects. The purpose of this study is to determine the validity and reliability of the Form Two Algebraic Expression Self-Assessment Learning questionnaire instrument. The questionnaire was validated through face validity and content validity of the instrument involving five experts in Mathematics and two experts in Language while construct validity and instrument reliability were analysed using the software Statistical Package of Social Science (SPSS) Version 27.0. A total of 145
\end{abstract}


Form Two students were involved in this study. The findings of the study showed that the item-content validity index (I-CVI) ranged from 0.800 to 1.000 and the scale-content validity index (S-CVI/Ave) was 0.973 . Content validity ratio (CVR) scores indicate that all items were verified as important by the experts. The factor loading for each item was in the range of 0.539 to 0.846 while the results of the reliability analysis were $\alpha=0.950$. The results show that the instrument has high validity and reliability, thus it is suitable to be used for Form Two students to assess the learning of Algebraic Expressions on the cognitive domains of knowledge, understanding and application. The implication of this study is that teachers will get information about students' learning of Algebraic Expressions directly from the constructed instruments.

Keywords: validity, reliability, learning of algebraic expressions, cognitive domains, selfassessment

\section{Pengenalan}

Matematik adalah mata pelajaran yang selalu ada dalam setiap peringkat pendidikan. Mulai dari pendidikan rendah hingga pendidikan tinggi selalu ada kaitan dengan pembelajaran Matematik. Kurikulum Pendidikan di Malaysia menekankan perkembangan kemahiran kognitif dalam Matematik agar pelajar dapat berfikir secara logik dan sistematik dalam menyelesaikan masalah (Bahagian Pembangunan Kurikulum, 2017). Setiap pelajar yang menguasai kemahiran Matematik dengan baik adalah lebih bersedia untuk masa depan kerana Matematik digunakan dalam kehidupan seharian. Namun begitu, tidak semua pelajar dapat menguasainya dengan baik terutama dalam pembelajaran Ungkapan Algebra. Pelajar menghadapi masalah untuk menguasai Matematik dan antara topik yang sering menjadi masalah adalah Ungkapan Algebra (Ali \& Abu Bakar, 2007; Foo et al., 2021). Pengetahuan Algebra merupakan salah satu pengetahuan yang diperlukan dalam menguasai pembelajaran Matematik dan Matematik Tambahan kerana bermula dari pendidikan rendah hingga pendidikan tinggi selalu ada kaitan dengan pembelajaran Algebra. Menurut Mohd Faizal et al. (2016) pembelajaran Algebra merangkumi konsep, hukum dan rumus Algebra di peringkat menengah rendah berhubung kait dengan menengah atas. Maka, pengetahuan, kefahaman yang jelas dan penguasaan yang kukuh tentang konsep Algebra adalah penting untuk membantu pelajar membina kemahiran Matematik, meningkatkan kemahiran kognitif, mengembangkan strategi dan kaedah yang lebih berkesan semasa menyelesaikan masalah Algebra (Tan, 2015).

\section{Sorotan Literatur}

\section{Ungkapan Algebra dalam Matematik}

Ungkapan Algebra adalah satu daripada cabang ilmu dalam Matematik. Tahap pengetahuan dan kefahaman konsep Ungkapan Algebra yang kuat akan membantu pelajar mengembangkan kemahiran berfikir, strategi yang tepat dan berkesan semasa mereka menyelesaikan masalah dan apabila mereka berdepan dengan masalah dalam kehidupan seharian. Pengetahuan dan kefahaman tentang Ungkapan Algebra adalah penting kerana bukan sahaja operasi tambah, tolak, darab, bahagi, pecahan dan nombor negatif yang menjadi asas dalam Ungkapan Algebra tetapi juga persediaan mental dan untuk perkembangan intelektual yang berterusan dalam diri pelajar. Terdapat banyak topik Matematik memerlukan pengetahuan Algebra sebagai asas dalam membangunkan pengetahuan dan kefahaman seperti geometri, ketaksamaan linear, persamaan linear dan sebagainya. Selain itu, Algebra juga merupakan domain kandungan utama dalam pentaksiran Trend in International Mathematic and Science Study (TIMSS) dan Programme International Students Assessment (PISA) dan telah merangkumi jumlah soalan yang majoriti dalam pentaksiran. Selanjutnya, Ungkapan Algebra juga merupakan topik penting yang diuji dalam Penilaian Menengah Rendah (PMR), Sijil Pelajaran Malaysia (SPM) dan Sijil Pendidikan Malaysia (MCE) (Yusoff \& Ainun, 2019). Oleh itu, kecekapan dalam menyelesaikan masalah Ungkapan Algebra sangat dititikberatkan bagi menentukan pencapaian Matematik pelajar dalam peperiksaan awam. Pengajaran dan pembelajaran Algebra adalah sesuatu yang sukar (Egodawatte, 
2011; Foo et al., 2017; Marpa, 2019; Sazilah Sam \& Mohd Faizal, 2017) kerana penggunaan pemboleh ubah, huruf dan simbol dalam Algebra mengelirukan pelajar (Booth,1981; Lodholz, 1999; Lucariello et al., 2013; Mcintyre, 2007). Di samping itu, pelajar menghadapi masalah dari segi kesukaran bahasa dalam mempelajari simbol-simbol, tatatanda dan istilah-istilah Matematik (Azrul \& Marlina, 2007). Justeru dalam proses pembelajaran, kebolehan kognitif pelajar dalam menyelesaikan masalah Matematik sering dijadikan suatu penanda aras dalam menilai pencapaian pelajar menguasai Matematik.

\section{Domain Kognitif (Pengetahuan, Kefahaman dan Aplikasi) dalam Pembelajaran Ungkapan Algebra}

Kemahiran kognitif dan penguasaan konsep Algebra dalam kalangan pelajar harus dititikberatkan dan diperkembangkan sejak awal lagi. Pencapaian pelajar yang lemah dalam Ungkapan Algebra ini sebenarnya bertitik tolak dari kebolehan dan kemahiran kognitif pelajar pada domain pengetahuan, kefahaman dan aplikasi yang tidak dikembangkan dengan baik semasa menyelesaikan masalah Ungkapan Algebra. Zainudin (1995) serta Bayat dan Meamar (2016) juga mengesahkan bahawa pencapaian pelajar dalam topik Ungkapan Algebra kurang memuaskan disebabkan masalah berkaitan kemahiran kognitif pelajar. Hal ini juga telah dibuktikan melalui laporan TIMSS yang telah menguji apa yang telah dipelajari oleh pelajar Tingkatan Dua di Malaysia dalam Sains dan Matematik. Kerangka pentaksiran Matematik TIMSS merangkumi dua aspek iaitu domain kandungan (Nombor (30\%), Algebra (30\%), Geometri (20\%), Data dan Kebarangkalian (20\%)) dan domain kognitif (pengetahuan (35\%), Aplikasi (40\%) dan Penaakulan (25\%)). Laporan kebangsaan TIMSS (2019) menunjukkan bahawa, pencapaian pelajar Malaysia dalam domain Algebra bagi tahun 2007, 2011 dan 2019 adalah paling rendah berbanding dengan ketiga-tiga domain Nombor, Geometri, Data Dan Kebarangkalian (Bahagian Perancangan dan Penyelidikan Dasar Pendidikan, 2020). Laporan TIMSS (2019) juga melaporkan bahawa kurang daripada 50\% pelajar Malaysia menjawab item Algebra dengan betul dalam domain kognitif pengetahuan, aplikasi dan penaakulan (33.6\% untuk Item 2 dan 37.45\% untuk item 3). Purata skor pencapaian Malaysia 2019 dalam domain kognitif pengetahuan mencatatkan nilai paling rendah (451) berbanding aplikasi (464) dan penaakulan (462). Ini menunjukkan bahawa sebilangan besar pelajar masih berdepan dengan masalah untuk menguasai pengetahuan dan kefahaman konsep asas dalam Matematik terutama topik Ungkapan Algebra.

Pencapaian dalam topik Ungkapan Algebra adalah bergantung kepada pengetahuan dan kefahaman konseptual dan prosedural seseorang pelajar (Adeleke, 2007; Joffrion, 2005). Kesukaran pelajar dari segi konseptual iaitu kesukaran dalam menentukan dan memberi makna pemboleh ubah, penggunaan huruf dan simbol sebagai pemboleh ubah (Booth,1981; Lodholz, 1999; Lucariello et al., 2013; Mcintyre, 2007), pekali dan pemalar (Booth, 1988), memahami Ungkapan Algebra (Egodawatte, 2011; Ling et al., 2016; Marpa, 2019), memahami istilah abstrak dan memanipulasi simbol dan nombor (Kuchemann,1981; MacGregor \& Stacey, 1997; Sangit, 2007). Manakala kesukaran yang dialami dari segi prosedur adalah penerapan konsep, peraturan dan prinsip aritmetik dan operasinya (Herscovics \& Linchevscki, 1994; Warren, 2003), operasi asas dalam tajuk nombor negatif (Khamsan Omar, 1999; Yusoff \& Ainun, 2019), melaksanakan penambahan dan penolakan Ungkapan Algebra, penerapan konsep pendaraban dan pembahagian Ungkapan Algebra, mempermudah Ungkapan Algebra, kembangan, pemfaktoran, dan penyelesaian masalah berayat (Marpa 2019; Radah Krishna, 2015; Sangit, 2007; Sugiarti \& Retnawati 2019; Yusoff \& Ainun, 2019).

Oleh itu dapat dikaitkan kenapa kebanyakan pelajar masih lagi menghadapi masalah untuk menjawab soalan-soalan Ungkapan Algebra yang melibatkan soalan-soalan pengetahuan, kefahaman dan aplikasi. Sehubungan itu, adalah wajar penilaian kognitif terus dikaji di pelbagai jenis sekolah dan aliran kerana kemampuan kognitif diramal menjadi penentu kepada pencapaian seseorang pelajar (Bayat \& Tarmizi, 2010; Bayat \& Meamar, 2016; Tan 2015; Zainudin, 1995). Justeru, pengkaji mendapati adalah sukar untuk mendapatkan satu instrumen yang khusus bagi pelajar dalam menilai diri sendiri dari segi pencapaian, kemahiran dan kefahaman mereka dalam pembelajaran Algebra. Kebanyakan penilaian terhadap pencapaian pelajar dinilai oleh guru mata pelajaran mereka. Dalam proses pembelajaran dan pengajaran, pelajar merupakan penilai terbaik terhadap pembelajaran mereka (Mohammad Najib, 2011). Pembelajaran kendiri membolehkan pelajar lebih mengetahui dan memahami apa yang mereka pelajari (Mohd Faizal \& Leow, 2017). Guru tidak mungkin akan mengetahui apa yang pelajar benar-benar tahu 
atau berupaya mengetahui. Namun, kadang-kadang pelajar itu sendiri juga tidak mengetahui keupayaan sendiri tanpa membuat refleksi, pertimbangan dan penilaian. Dengan adanya instrumen penilaian kendiri ini, ia membolehkan pelajar menilai dan seterusnya mengenal keupayaan diri sendiri. Justeru, usaha membangunkan instrumen penilaian kendiri Pembelajaran Ungkapan Algebra berasaskan domain kognitif ini menepati keperluan dan keadaan semasa, di samping sebagai sumbangan kecil pengkaji dalam merungkai keadaan sebenar tahap penguasaan pelajar Tingkatan Dua dalam pembelajaran Ungkapan Algebra di sekolah.

\section{Tujuan Kajian}

Kajian ini bertujuan untuk menguji kesahan dan kebolehpercayaan soal selidik penilaian kendiri pembelajaran Ungkapan Algebra pelajar Tingkatan Dua.

\section{Metod Kajian}

Kajian ini menggunakan reka bentuk kajian kuantitatif dengan kaedah tinjauan. Pengkaji telah mengedarkan borang soal selidik kepada 145 orang pelajar Tingkatan Dua di Tawau, Sabah. Lokasi kajian ditentukan dengan mengambil kira faktor demografi iaitu lokasi sekolah (bandar dan sekolah luar bandar). Pengkaji menggunakan teknik persampelan berstrata berkadar dan memilih sampel secara rawak, iaitu bagi memungkinkan kebarangkalian setiap populasi dipilih daripada setiap kumpulan atau strata terlibat. Pengkaji mendapat kerjasama baik daripada pihak Jabatan Pendidikan Negeri Sabah, Pejabat Pendidikan Daerah Tawau, pentadbir sekolah serta guru-guru Matematik Tingkatan Dua di sekolah terlibat. Selanjutnya, sebelum borang soal selidik ditadbir kepada pelajar, pautan google forms borang soal selidik beserta panduan dan arahan disediakan dan dijelaskan kepada guru-guru Matematik Tingkatan Dua di sekolah berkenaan.

\section{Instrumen Soal Selidik}

Instrumen yang digunakan dalam kajian ini ialah soal selidik yang dibina oleh pengkaji sendiri berasaskan domain kognitif Taksonomi Bloom. Pengkaji meneroka pelbagai sumber rujukan seperti jurnal dan artikel daripada kajian-kajian terdahulu sebagai sumber bacaan dan literatur tambahan untuk menyokong dan memperkukuhkan soal selidik. Pengkaji juga meneroka instrumen-instrumen berkaitan yang pernah dibina sebelum ini bertujuan untuk mengetahui konstruk dan item yang telah dibina. Hal ini penting kerana sekiranya terdapat konstruk atau item yang bersesuaian, ia boleh diubahsuai mengikut kesesuaian konteks kajian ini.

Soal selidik ini mengehendaki pelajar menentukan persepsi mereka secara jujur melalui penilaian kendiri terhadap pembelajaran Ungkapan Algebra dari domain pengetahuan, kefahaman dan aplikasi. Soal selidik mengandungi dua bahagian iaitu bahagian A berkaitan dengan demografi pelajar dan bahagian B berkaitan dengan penilaian kendiri pelajar terhadap pembelajaran Ungkapan Algebra. Soal selidik bahagian A iaitu ciri-ciri demografi dibuat menggunakan skala nominal sementara bahagian B menggunakan skala sela. Dalam kajian ini, pengkaji telah memilih menggunakan kaedah pemungutan data menggunakan skala interval 5 mata sebagai skala jawapan responden terhadap semua penyataan yang digunakan dalam soal selidik. Skala interval sesuai digunakan untuk mengukur sifat atau pandangan yang diberikan oleh responden secara berterusan terhadap suatu amalan persepsi, pengetahuan atau sikap (Budiaji, 2013). Dalam instrumen ini, responden memilih jawapan dengan menandakan salah satu dari nombor 1 (Sangat Tidak Setuju) hingga 5 (Sangat Setuju).

Instrumen berbentuk soal selidik ini digubal dengan mengemukakan beberapa pernyataan bagi mendapatkan maklum balas dan penilaian pelajar dalam pembelajaran Ungkapan Algebra. Sebanyak 21 item telah dibina dan dipecahkan kepada tiga sub-konstruk iaitu domain pengetahuan, kefahaman dan aplikasi. Bilangan dan pecahan item mengikut sub-konstruk bagi instrumen ini ditunjukkan pada Jadual 1 
DOI: https://doi.org/10.47405/mjssh.v6i11.1136

Jadual 1: Taburan Item Mengikut Sub-konstruk dalam Instrumen Soal Selidik

\begin{tabular}{llll}
\hline Konstruk & Sub-konstruk & Nombor Item & Bilangan Item \\
\hline Penilaian Kendiri & Pengetahuan & P1-P7 & 7 \\
Pembelajaran & Kefahaman & P8-P16 & 9 \\
Ungkapan Algebra & Aplikasi & P17-P21 & 5 \\
\hline Jumlah item & & & 21 \\
\hline
\end{tabular}

Bagi memastikan instrumen soal selidik mempunyai kesahan yang tinggi dari aspek kesahan kandungan dan kesahan muka pengkaji telah mendapatkan pendapat daripada beberapa orang pakar dalam bidang yang berkaitan. Semakan pakar adalah perlu untuk memastikan ketepatan konstruk serta kejelasan kandungan (Kline, 2005). Justeru itu, jasa baik tujuh orang panel pakar digunakan untuk menilai dan memurnikan soal selidik yang dibina dan memberi skor, ulasan serta cadangan menyeluruh untuk penambahbaikan. Lima orang panel pakar dalam bidang Matematik iaitu Pensyarah Universiti, Pegawai Nazir Matematik, Pegawai Sisc+ Sains dan Matematik, pemeriksa kertas Matematik (SPM) dan guru berpengalaman dilantik untuk menilai dan mengesahkan kandungan soal selidik. Manakala dua orang pakar bahasa iaitu Jurulatih Utama Bahasa Melayu dan Ketua Bidang Bahasa dilantik untuk membuat kesahan muka berdasarkan penggunaan bahasa dan ketepatan penggunaannya dalam soal selidik. Penilaian oleh pakar ini juga bertujuan untuk memastikan item soal selidik bersesuaian dan boleh digunakan terhadap responden. Berdasarkan penilaian panel pakar bahasa, mereka bersetuju bahawa laras bahasa, penggunaan tatabahasa adalah mudah difahami dan tempoh masa menjawab soal selidik adalah mencukupi dan bersesuaian.

Bagi kesahan kandungan pula, setelah mendapat persetujuan dan penilaian daripada panel pakar, kesahan kandungan instrumen soal selidik diukur dengan prosedur pengukuran kuantitatif kesahan kandungan oleh Lawshe (1975) iaitu Nisbah Kesahan Kandungan (Content Validity Ratio atau CVR) dan Indeks Kesahan Kandungan (Content Validity Indeks atau CVI). CVR digunakan bagi mengukur kesahan kandungan item melalui pengukuran empirikal (Matore et al., 2017). Menerusi pengiraan CVR ini membantu pengkaji membuat keputusan untuk mengekalkan atau menggugurkan item pada instrumen. CVR juga bertujuan menapis item secara empirikal pada instrumen dengan prosedur kuantitatif bagi memastikan setiap item benar-benar mewakili kandungan domain konstruk (Yusoff, 2019). Nilai CVR adalah berada dalam julat -1 sehingga +1 , di mana nilai yang hampir kepada +1 menunjukkan pakar bersetuju bahawa item itu sangat penting dalam kesahan kandungan. Selepas nilai CVR bagi setiap item dikenal pasti, item yang berada di bawah nilai 0.50 melambangkan kesahan yang diragui dan diganti dengan item baharu (Mohamed et al., 2017). Instrumen soal selidik memberikan nilai CVR bagi setiap item di antara 0.6 sehingga +1 (Jadual 2) dan menunjukkan semua item adalah dikekalkan dan disahkan penting dan mewakili domain konstruk.

Selepas nilai CVR bagi setiap item dikenal pasti, nilai CVI akan dikira secara keseluruhan. Bagi instrumen baru pengkaji mesti mendapatkan nilai CVI bersamaan 0.8 dan ke atas bagi membuktikan item-item mempunyai kesahan kandungan yang tinggi, jelas dan relevan (Lau et al., 2018; Shrotryia \& Dhanda, 2019). Terdapat pengkaji lepas yang mencadangkan nilai 0.78 dan ke atas bagi kes tiga atau lebih panel pakar dianggap memiliki kesahan kandungan yang baik (Polit et al., 2007). Instrumen soal selidik kajian ini memberikan nilai CVI 0.973 (Jadual 2) berdasarkan persetujuan dan penilaian panel pakar secara keseluruhannya iaitu $(\mathrm{N}=5)$. Oleh itu, berdasarkan nilai CVR dan CVI dapat dirumuskan bahawa instrumen soal selidik memiliki kesahan kandungan yang baik dan diterima. Rumus pengiraan CVR dan CVI seperti berikut;

$\mathrm{CVRi}=\frac{\left[n_{e}-(N / 2)\right]}{N / 2}$

$\mathrm{n}_{\mathrm{e}}=$ jumlah panel pakar yang menilai item sebagai penting

$\mathrm{N}=$ jumlah keseluruhan panel pakar terlibat

$$
\begin{aligned}
& \text { I-CVI }=\frac{\text { Item Yang Diterima (Skor } 3 \text { Atau 4) }}{\text { Bilangan Pakar }} \\
& \text { S-CVI/Ave }=\frac{\text { Jumlah skor I-CVI }}{\text { bilangan item }}
\end{aligned}
$$


S-SVI/UA $=\frac{\text { Jumlah skor UA }}{\text { bilangan item }}$

Jadual 2: Indeks Kesahan Kandungan (CVI) Dan Nisbah Kesahan Kandungan (CVR) Soal Selidik Penilaian Kendiri Pembelajaran Ungkapan Algebra

\begin{tabular}{lllllllll}
\hline Item & Pakar & $\begin{array}{l}\text { Pakar } \\
\mathbf{2}\end{array}$ & $\begin{array}{l}\text { Pakar } \\
\mathbf{3}\end{array}$ & $\begin{array}{l}\text { Pakar } \\
\mathbf{4}\end{array}$ & $\begin{array}{l}\text { Pakar } \\
\mathbf{5}\end{array}$ & $\begin{array}{l}\text { Persetujuan } \\
\text { Pakar }\end{array}$ & $\begin{array}{l}\text { I- } \\
\text { CVI }\end{array}$ & CVR \\
\hline Item 1 & 1 & 1 & 1 & 1 & 1 & 5 & 1.000 & 1 \\
Item 2 & 1 & 1 & 1 & 1 & 1 & 5 & 1.000 & 1 \\
Item 3 & 1 & 1 & 1 & 1 & 1 & 5 & 1.000 & 1 \\
Item 4 & 0 & 1 & 1 & 1 & 1 & 4 & 0.800 & 0.6 \\
Item 5 & 1 & 1 & 1 & 1 & 1 & 5 & 1.000 & 1 \\
Item 6 & 1 & 1 & 1 & 1 & 1 & 5 & 1.000 & 1 \\
Item 7 & 1 & 1 & 1 & 1 & 1 & 5 & 1.000 & 1 \\
Item 8 & 1 & 1 & 1 & 1 & 1 & 5 & 1.000 & 1 \\
Item 9 & 0 & 1 & 1 & 1 & 1 & 4 & 0.800 & 0.6 \\
Item 10 & 1 & 1 & 1 & 1 & 1 & 5 & 1.000 & 1 \\
Item 11 & 1 & 1 & 1 & 1 & 1 & 5 & 1.000 & 1 \\
Item 12 & 1 & 1 & 1 & 1 & 1 & 5 & 1.000 & 1 \\
Item 13 & 1 & 1 & 1 & 1 & 1 & 5 & 1.000 & 1 \\
Item 14 & 1 & 1 & 1 & 1 & 1 & 5 & 1.000 & 1 \\
Item 15 & 1 & 1 & 1 & 1 & 1 & 5 & 1.000 & 1 \\
Item 16 & 1 & 1 & 1 & 1 & 1 & 5 & 1.000 & 1 \\
Item 17 & 1 & 1 & 1 & 1 & 1 & 5 & 1.000 & 1 \\
Item 18 & 1 & 1 & 1 & 1 & 1 & 5 & 1.000 & 1 \\
Item 19 & 1 & 1 & 1 & 1 & 1 & 5 & 1.000 & 1 \\
Item 20 & 1 & 1 & 0 & 1 & 1 & 4 & 0.800 & 0.6 \\
Item 21 & 1 & 1 & 1 & 1 & 1 & 5 & 1.000 & 1 \\
Item 22 & 1 & 1 & 1 & 1 & 1 & 5 & 1.000 & 1 \\
\hline Proportion & \multirow{2}{*}{0.909091} & 1 & 0.954545 & 1 & 1 & S-CVI/Ave & 0.973 & \\
relevance & & 1 & & & & & & \\
\hline
\end{tabular}

\section{Hasil Kajian}

\section{Ujian Kenormalan Kajian Rintis}

Ujian kenormalan taburan data kajian rintis dilakukan ke atas soal selidik. Penentuan normaliti data diukur melalui kriteria nilai kepencongan (skewness) dan kecerunan (kurtosis), berdasarkan indikator julat nilai -1.96 dan +1.96 (Tabachnick \& Fidell, 1996; Hair et al., 2010). Jadual 3 menunjukkan dapatan analisis nilai skewness dan kurtosis soal selidik adalah normal.

Jadual 3: Analisis Keputusan Ujian Taburan Normaliti Kajian Rintis

\begin{tabular}{llllll}
\hline & $\begin{array}{l}\text { N } \\
\text { Statistics }\end{array}$ & $\begin{array}{l}\text { Skewness } \\
\text { Statistic }\end{array}$ & $\begin{array}{l}\text { Std. } \\
\text { Error }\end{array}$ & $\begin{array}{l}\text { Kurtosis } \\
\text { Statistic }\end{array}$ & $\begin{array}{l}\text { Std. } \\
\text { Error }\end{array}$ \\
\hline $\begin{array}{l}\text { Penilaian Kendiri } \\
\begin{array}{l}\text { Pembelajaran Ungkapan } \\
\text { Algebra }\end{array}\end{array}$ & 145 & -.498 & .201 & .733 & .400 \\
\hline
\end{tabular}


DOI: https://doi.org/10.47405/mjssh.v6i11.1136

\section{Keputusan Analisis Faktor Penerokaan (EFA)}

Analisis Faktor Penerokaan (EFA) dijalankan setelah data kajian rintis diperolehi bagi menentukan kesahan konstruk instrumen soal selidik. Jadual 4 menunjukkan nilai signifikan bagi ujian Kaiser Meyer Olkin (KMO) dan Ujian Kesferaan Bartlett kajian ini. Keputusan menunjukkan data ini memenuhi syarat kebolehfaktoran untuk melaksanakan analisis faktor.

Jadual 4: Nilai Kaiser Meyer Olkin dan Signifikan Konstruk

\begin{tabular}{lllll}
\hline Konstruk & $\begin{array}{l}\text { Kaiser-Meyer- } \\
\text { Olkin }\end{array}$ & $\begin{array}{l}\text { Bartlett's Test of Sphericity } \\
\text { Approx. df Sig } \\
\text { Chi-Square }\end{array}$ & \\
\hline $\begin{array}{l}\text { Penilaian Kendiri } \\
\begin{array}{l}\text { Pembelajaran Ungkapan } \\
\text { Algebra }\end{array}\end{array}$ & .918 & 2218.019 & 231 & .000 \\
\hline
\end{tabular}

Jadual 5 menunjukkan keputusan komponen dan Total Variance Explained bagi soal selidik. Jumlah keseluruhan varians bagi mengukur konstruk penilaian kendiri pembelajaran Ungkapan Algebra adalah 63.674\%. Keputusan menunjukkan bilangan komponen dan item bagi setiap komponen adalah bersesuaian mengukur konstruk kerana jumlah varians keseluruhan melebihi 60\% (Hair et al., 2010). Berdasarkan keputusan tersebut, terdapat tiga faktor utama yang memberi sumbangan besar kepada perubahan varians secara keseluruhan dalam konstruk penilaian kendiri pembelajaran Ungkapan Algebra.

Jadual 5 : Keputusan Bilangan Komponen dan Total Variance Explained Penilaian Kendiri Pembelajaran Ungkapan Algebra

\begin{tabular}{lllllll}
\hline \multirow{2}{*}{ Component } & \multicolumn{3}{l}{ Extraction Sums of Squared Loadings } & \multicolumn{3}{l}{ Rotation Sums of Squared Loadings } \\
\cline { 2 - 7 } & Total & $\begin{array}{l}\text { \% of } \\
\text { variance }\end{array}$ & $\begin{array}{l}\text { Cumulative } \\
\text { \% }\end{array}$ & Total & $\begin{array}{l}\text { \% of } \\
\text { Variance }\end{array}$ & Cumulative \\
\hline 1 & 10.668 & 50.799 & 50.799 & 4.989 & 23.759 & 23.759 \\
2 & 1.428 & 6.800 & 57.599 & 4.357 & 20.747 & 44.506 \\
3 & 1.276 & 6.076 & 63.674 & 4.025 & 19.168 & 63.674 \\
\hline
\end{tabular}

Seterusnya, Jadual 6 menunjukkan muatan faktor bagi setiap item dalam setiap komponen dan bilangan item setiap komponen yang telah berjaya diekstrak. Didapati, bilangan item setiap komponen menepati cadangan Pallant (2012), iaitu minimum tiga item untuk menerangkan satu komponen atau faktor. Hair et al. (2010) menetapkan bacaan muatan faktor 0.50 atau lebih tinggi, dianggap sangat baik secara praktikal dalam menentukan faktor dalam sesuatu skala pengukuran. Secara keseluruhannya, muatan faktor setiap item berada dalam julat 0.539 hingga 0.846 .

Jadual 6: Muatan Faktor Setiap Item Bagi Konstruk Penilaian Kendiri Pembelajaran Ungkapan Algebra

\begin{tabular}{lll}
\hline \multirow{2}{*}{ Item } & \multicolumn{2}{c}{ Komponen } \\
\cline { 2 - 3 } & $\mathbf{1}$ & $\mathbf{2}$ \\
\hline Saya memahami aritmetik dan operasinya & .561 & \\
Saya boleh menjelaskan pekali dan pemalar suatu Ungkapan & .560 \\
Algebra & .601 \\
Saya boleh membina Ungkapan Algebra & .539 \\
Saya memahami pendaraban dan pembahagian Ungkapan & \\
Algebra & .595 \\
Saya boleh mengeneralisasikan tentang pendaraban berulang & \\
Ungkapan Algebra & \\
Saya boleh menjelaskan maksud kembangan dua Ungkapan & .700
\end{tabular}


Algebra

Saya memahami konsep pemfaktoran Ungkapan Algebra $\quad .561$

Saya memahami konsep kembangan Ungkapan Algebra $\quad .745$

Saya memahami pelbagai kaedah dalam melaksanakan

pemfaktorkan Ungkapan Algebra

Saya dapat melaksanakan pengiraan yang melibatkan

penambahan dan penolakan Ungkapan Algebra

.761

Saya dapat melaksanakan pengiraan yang melibatkan

pendaraban dan pembahagian Ungkapan Algebra

Saya dapat mempermudah Ungkapan Algebra yang melibatkan

gabungan operasi

Saya mengaplikasikan konsep kembangan dalam

menyelesaikan masalah

Saya mengaplikasikan konsep pemfaktoran dalam

menyelesaikan masalah

Saya mempunyai pengetahuan tentang pemboleh ubah

Saya mempunyai pengetahuan tentang simbol dan tata tanda

Matematik

Saya boleh pengenalpastian huruf atau simbol yang mewakili

suatu pemboleh ubah

Saya boleh mengenal pasti sebutan, sebutan serupa dan sebutan

tak serupa

Saya boleh menyatakan faktor sepunya suatu Ungkapan

Algebra

Saya boleh menjelaskan konsep pemboleh ubah dalam

Ungkapan Algebra

Saya boleh menjelaskan huruf atau simbol dalam Ungkapan

Algebra

\section{Ujian Kebolehpercayaan Kajian Rintis}

Kesemua konstruk dalam instrumen kajian diukur dan dianalisis bagi mendapatkan nilai pekali kebolehpercayaan dengan menggunakan analisis kebolehpercayaan Alfa Cronbach. Didapati nilai pekali kebolehpercayaan yang diperoleh bagi setiap konstruk adalah dalam lingkungan 0.843 hingga 0.919. Hal ini menunjukkan semua item di bawah setiap konstruk memberikan nilai kebolehpercayaan yang tinggi menunjukkan semua item boleh diterima dan sesuai digunakan untuk kajian. Nilai pekali kebolehpercayaan bagi setiap konstruk dan secara keseluruhan ditunjukkan dalam Jadual 7.

Jadual 7: Nilai Pekali Kebolehpercayaan Instrumen Kajian

\begin{tabular}{ccc}
\hline Konstruk & Bilangan Item & Nilai Pekali Kebolehpercayaan \\
\hline Pengetahuan & 7 & 0.884 \\
Kefahaman & 9 & 0.919 \\
Aplikasi & 5 & 0.843 \\
\hline Keseluruhan & $\mathbf{2 1}$ & $\mathbf{0 . 9 5 0}$ \\
\hline
\end{tabular}

\section{Perbincangan}

Analisis keputusan kesahan muka, kesahan kandungan dan kesahan konstruk soal selidik yang melibatkan pemeriksaan oleh tujuh orang pakar didapati sesuai untuk digunakan bagi mengukur konstruk yang dikaji. Seterusnya, analisis faktor yang dijalankan untuk mendapat kesahan konstruk menunjukkan nilai muatan faktor bagi setiap item adalah melebihi 0.50 seperti yang ditetapkan (Hair et al., 2010). Hasil keputusan analisis yang diperoleh mengesahkan bahawa kesemua item adalah sah diguna pakai dalam menjalankan kajian sebenar dan nilai kebolehpercayaan instrumen adalah, $\alpha=$ 
0.950 iaitu sangat baik dan efektif dengan konsistensi yang tinggi (Bond \& Fox, 2015; Stephanie, 2014).

\section{Kesimpulan}

Untuk memastikan instrumen yang dibangunkan dapat digunakan berulang kali, pembinaan instrumen mesti dilakukan dengan tepat dan betul dari segi kesahan dan kebolehpercayaan. Instrumen yang telah dibina dengan betul tidak akan menghadapi masalah dalam mengukur konstruk yang dikaji (Hassan et al., 2019). Pembinaan dan pengesahan soal selidik kajian ini telah mengambil kira semakan pakar dalam bidang Matematik dan disokong dengan hasil analisis. Kesahan dan kebolehpercayaan soal selidik yang dibina membuktikan soal selidik ini merupakan suatu alat kajian yang mempunyai kesahan dan kebolehpercayaan yang tinggi. Justeru, soal selidik ini boleh digunakan untuk mengenal pasti domain kognitif (pengetahuan, kefahaman dan aplikasi) terhadap pembelajaran Ungkapan Algebra melalui penilaian kendiri pelajar Tingkatan Dua.

\section{Rujukan}

Adeleke, M. A. (2007). Strategic improvement of mathematical problem-solving performance of secondary school students using procedural and conceptual learning strategies. Educational Resarch and Review, 2(9), 259-263.

Ali, M. dan Abu Bakar, N. (2007). Tahap Kefahaman Pelajar Tingkatan Empat dalam Tajuk Ungkapan Algebra. Fakulti Penddikan: Universiti Teknologi Malaysia

Azrul Fahmi \& Marlina Ali. (2007). Analisis Kesilapan dalam Tajuk Ungkapan Algebra di Kalangan Pelajar Tingkatan Empat.

Bahagian Pembangunan Kurikulum. (2017). Dokumen Standard Kurikulum dan Pentaksiran (DSKP) Matematik Tingkatan 1 dan 2. Putrajaya: Kementerian Pendidikan Malaysia.

Bahagian Perancangan dan Penyelidikan Dasar Pendidikan. (2020). Laporan Kebangsaan TIMSS 2019 Trends in International Mathematics and Science Study. Cetakan Pertama. Purajaya: Kementerian Pendidikan Malaysia.

Bayat, S., \& Meamar, A. (2016). Predicting Algebra Achievement: Cognitive and Meta cognitive Aspects. Procedia - Social and Behavioral Sciences, 217, 169-176.

Bayat, S., \& Tarmizi, R. A. (2010). Assessing Cognitive and Metacognitive Strategies During Algebra Problem Solving Among University Students. Procedia-Social and Behavioral Sciences, 8, $403-$ 410.

Bond, T.G dan Fox, C.M. (2007). Applying The Rasch Model: Foundamental Maeasurement in the Human Sciences. $2^{\text {nd }}$ Ed. London: Lawrence ErlboumAssociates, Publisers. Mahwah, New Jersey. 200-225.

Booth, L. R. (1981). Child Methods in Secondary Mathematics. Educational Studies in Mathematics, 12, 29-41. https://doi.org/10.1007/BF00386044

Budiaji, W. (2013). Skala pengukuran dan jumlah respon skala likert. Jurnal ilmu pertanian dan perikanan, 2(2), 127-133.

Egodawatte, G. (2011). Secondary school students' misconceptions in algebra. Unpublished Ph.D. Thesis, University of Toronto, Canada. Retrieved from https://tspace.library. utoronto.

Foo, J. Y., Abdullah, M. F. N. L., Adenan, N. H., \& Hoong, J. Y. (2021). Kajian keperluan pembangunan modul latihan berasaskan Kemahiran Berfikir Aras Tinggi bagi topik Ungkapan Algebra tingkatan satu. Jurnal Pendidikan Bitara UPSI, 14, 33-40.

Hair, J. F., Black, W. C., Babin, B. J., \& Anderson, R. E. (2010). Multivariate data analysis (7th ed.). Prentice Hall.

Hassan, N. F., Puteh, S., Muhamad Sanusi, A., \& Che Mohamad Zahid, N. H. (2019). Student perspective on technology enabled/enhanced active learning in educational: Rasch measurement model. International Journal of Engineering and Advanced Technology, 8(6 Special Issue 3), 929-935. https://doi.org/10.35940/ijeat.F1061.0986S319

Herscovics, N and Linchevski, L. (1994). A Cognitive Gap Between Arithmetics and Algebra. Educational studies in Mathematics, 27, 59-78. 
Joffrion, H. K. (2005). Conceptual and Procedural Understanding of Algebra Concepts in the Middle Grades. December, 79.

Kline, T. (2005). Psychological testing: A practical approach to design and evaluation. Sage.

Lau, A. S. Y., Yusoff, M. S. B., Lee, Y. Y., Choi, S. B., Xiao, J. Z., \& Liong, M. T. (2018). Development and validation of a Chinese translated questionnaire: A single simultaneous tool for assessing gastrointestinal and upper respiratory tract related illnesses in pre-school children. Journal of Taibah University Medical Sciences, 13(2), 135-141. https://doi.org/10.1016/j.jtumed.2017.11.003

Lawshe, C. H. (1975). A quantitative approach to content validity. Personnel psychology, 28(4), $563-$ 575.

Ling, G. C. L., Shahril, M., \& An, A. (2016). Common Misconceptions of Algebraic Problems: Identifying Trends and Proposing Possible Remedial Measures. Advanced Science Letter, 22, $1547-$ 1550. https://doi.org/10.1166/asl.2016.6675

Lodholz, r. (1999). The Transition from Arithmetic To Algebra. In B. Moses (Ed.), Algebraic Thinking, Grades K-12 (Pp.52-58). Reston, VA: National Council Of Teachers Of Mathematics.

Lucariello, J., Tine, M. T., \& Ganley, C. M. (2014). A formative assessment of students' algebraic variable misconceptions. The Journal of Mathematical Behavior, 33, 30-41.

MacGregor, M., \& Stacey, K. (1997). Students' Understanding Of Algebraic Notation : 11-15, Educational Studies In Mathematics, Vol.33, pp.1-19.

Marpa, E. P. (2019). Common Errors in Algebraic Expressions: A Quantitative- Qualitative Analysis. International Journal on Social and Education Sciences, 1(2)

Matore, M. E. E. M., Idris, H., Rahman, N. A., \& Khairani, A. Z. (2017). Kesahan Kandungan Pakar Instrumen IKBAR Bagi Pengukuran AQ Menggunakan Nisbah Kesahan Kandungan. In Proseeding of International Conference on Global Education V (ICGE V) (May) (pp. 979-997).

Mcintyre, Z. S. (2007). An Analysis of Variable Misconceptions Before and After Various Collage Level Mathematics Courses. Biography An Interdisciplinary Quarterly. The University of Maine

Mohd Faizal Nizam Lee Abdullah \& Leow Tze Wei (2017). Kesahan Dan Kebolehpercayaan Instrumen Penilaian Kendiri Pembelajaran Geometri Tingkatan Satu (Learning Form One Geometry: Validity and Reliability Of A Self-Evaluation Instrument). Malaysian Journal of Learning And Instruction: Vol. 14 No. 1 (2017): 211-265

Mohd Faizal Nizam Lee Abdullah, Leow Tze Wei \& Mohd Uzi Dollah (2016). Pembinaan instrumen penilaian kendiri pembelajaran algebra tingkatan empat. Jurnal Pendidikan Sains dan Matematik Malaysia (JPSMM UPSI), 6(2), 54-68.

Mohamad Najib Abdul Ghafar. (2011). Pembinaan dan analisi ujian bilik darjah. Johor Bahru: Penerbit Universiti Teknologi Malaysia Press.

Mohamed, Z., Lebar, O., \& Shamsuddin, S. (2017). Pembinaan Dan Penilaian Instrumen Ujian Aptitud Kemasukan Ke Institut Pengajian Tinggi Malaysia. Journal of Science and Mathematics Letters, 5 , $16-27$.

Pallant, J. (2012). SPSS Survival Manual, A Step By Step Guide To Data Analysis Using $\quad$ IMB SPSS (5th Editio.). Two Penn Plaza, New York, USA: The Mc Graw Hill Companies.

Polite, D. F., Beck, T., \& Owen, S. V. (2007). Focus on research methods is the CVI an acceptable indicator of content validity? Appraisal and recommendations. Research in Nursing and Health, 30, 459-467. http://doi.org/10.1002/nur

Radah Krishna, S. (2015). "Analisis Kesilapan dalam Pengembangan dan Pemfaktoran Ungkapan Aljabar dalam kalangan Pelajar Tingkatan Empat”. Tesis Ijazah Sarjana Sastera (Pendidikan).

Sangit, Z. (2007). Kesilapan dalam ungkapan algebra di kalangan pelajar tingkatan 4: satu kajian kes. Doctoral dissertation, Universiti Pendidikan Sultan Idris.

Shrotryia, V. K., \& Dhanda, U. (2019). Content Validity of Assessment Instrument for Employee Engagement. SAGE Open, 9(1), 1-7. https://doi.org/10.1177/2158244018821751

Stephanie, G. (2014). Cronbach's Alpha: Simple Definition, Use and Interpretation. Retrieved on 5 Mei 2021, from https://www.statisticshowto.datasciencecentral.com/cronbachs-alpha-spss/

Sugiarti, L \& Retnawati, H. (2019). Analysis of student difficulties on algebra problem solving in junior high school. https://doi.org/10.1088/1742-6596/1320/1/012103

Tabachnick, B. G., \& Fidell, L. S. (1996). Using Multivariate Statistics (3rd ed.). Harper Collins.

Tan Yew Hor (2015). "The Cognitive Diagnostic Assessment Of The Learning Of Algebraic Expressions For Form Two Students": Universiti Sains Malaysia. 
DOI: https://doi.org/10.47405/mjssh.v6i11.1136

Warren, E. (2003). The role of arithmetic structure in the transition from arithmetic to algebra. Mathematics Education Research Journal. https://doi.org/10.1007/BF03217374

Yusoff, M. S. B. (2019). ABC of content validation and content validity index calculation. Resource, $11(2), 49-54$.

Yusoff Daud \& Ainun Syakirah. (2019). Student Error Analysis in Learning Algebraic Expression: A Study in Secondary School Putrajaya. Creative Education, 10, 2615-2630. https://doi.org/10.4236/ce.2019.1012189

Zainudin Abas (1995). Kesilapan Algebra Dan Masalah Dalam Pendidikan Matematik Di Peringkat Sekolah Menengah. Berita matematik, 46, 9-1 